\title{
The Consistency Of Islamic Financial Sustainability In Covid-19 Pandemic: An Empirical Analysis
}

\author{
Yanuar Trisnowati $^{1 \mathrm{a}}$, Rini Dwiyani Hadiwidjaja ${ }^{2 b^{* *}}$, Tita Nurvita $^{1 \mathrm{c}}$ \\ ${ }^{1 \mathrm{a}, \mathrm{c}}$ School of Business, IPB University \\ Jl. Padjajaran,Bogor 16128, Indonesia \\ ${ }^{2} \mathrm{~b}^{*}$ Accounting Departement, Faculty of Economics, Universitas Terbuka \\ Jl. Cabe Raya. Pondok Cabe Pamulang. Tangerang Selatan 15418, Banten, Indonesia \\ Email: 'anuartrisnowati@apps.ipb.ac.id, ${ }^{b^{*}}$ dwiyani_rini@gmail.com, ${ }^{c}$ titanurvita@apps.ipb.ac.id \\ * Corresponding Author
}

\begin{abstract}
The concept of sustainability is the ability of a company to carry out work program activities in a sustainable manner to achieve company goals. This study aims to examine empirically the consistency of financial sustainability in Islamic companies before and during the Covid-19 pandemic. To measure the financial sustainability performance, this study used ratios from financial income and financial expenditure. The sample in this study used purposive sampling that is 14 Islamic companies on the Indonesia Stock Exchange. Multiple linear regression and a chow test were used to examine the consistency. The result showed that The financial sustainability ratio of companies at the time of the pandemic has a higher value than before the pandemic. the pandemic period in Indonesia affected the financial stability of companies listed on the Jakarta Islamic Index. The independent variable that affects the dependent variable experiences structural changes in Indonesia in the period 2019 to quarter II of 2020. According to the results above, investor should pay attention to financial stability while making investment decision, especially in turbulence like pandemic. Investors are expected to understand the behavior of company management in guiding investors regarding management's views on the company's future prospects.
\end{abstract}

Keywords: corporate governance; covid-19 pandemic; financial sustainability; macroeconomics

Article History: Received: November 242020 Accepted: March 42021 Published: April 52021

How to cite: Trisnowati, Y. et al. (2021) The Consistency of Islamic Corporate Financial Sustainability in Covid-19 Pandemic: An Empirical Analysis. Akrual: Jurnal Akuntansi (JA), 12(2): 179-192. DOI: https://doi.org/10.26740/jaj.v12n2.p179-192

\section{INTRODUCTION}

2020 has opened with several major events affecting global economic conditions. The outbreak of the Covid 19 virus started in China and finally on March 12, 2020, WHO announced to the world that the spread of the Covid 19 virus was a pandemic (Nuraini, S, \& Apri, 2020). Until mid-2020, WHO has confirmed more than thirteen million positive cases of infection worldwide with a death rate of nearly six hundred thousand people (https://covid19.who.int/, 2020). The spread of this epidemic has contributed to the decline in the world economy because several countries immediately implemented a regional 
quarantine policy followed by the closure of economic resources, the impact was that many companies had to lay off and even lay off employees. Efforts to reduce outbreaks of this viral disease have shown success in several regions of the country. Although several countries have succeeded in reducing the number of infections and deaths due to Covid 19, several countries are still implementing regional quarantine. The spread of this epidemic has an impact on the decline in the growth of several industrial sectors. The tourism industry and the aviation industry are examples of industrial sectors affected by the Covid 19 pandemic.

The case of the spread of the flu outbreak in the world was not the first time that occurred in 2020, in 1918 there was an outbreak of flu in the European region, namely the Spanish Flu. The Spanish flu has implications for the decline in the number of young people of productive age in European countries, one of which is Sweden (Karlsson, Nilsson, \& Pichler, 2014). The death rate due to flu is common among young people aged 15-40 years. As a result, several production sectors had to stop producing and subsequently increased the poverty rate in Sweden. In 2003 there was an outbreak of a disease known as Severe Acute Respiratory Syndrome (SARS) in the Asian region. This epidemic began to spread from the Guangdong region in China in 2002 and spread to regions in Asia. Recorded a significant number of deaths due to this disease in all Asian regions such as China, Hong Kong, Singapore, Indonesia, and Taiwan. The SARS outbreak in Taiwan affected the share prices of companies in the tourism sector and its ecosystem, companies in the healthcare industry (Chen Chun-Da , Chen Chin-Chun \& Bor-Yi, 2009), and the shares of companies in the biotechnology industry (Wang, Yang, \& Chen, 2013). The case of the Ebola virus which became an outbreak in the African region in around 2014 had an impact on financial market conditions in African countries. The outbreak caused by the Ebola virus has caused shock and reduced liquidity from the mutual fund industry in Africa which has also resulted in a decrease in the rate of economic growth (Del Giudice \& Paltrinieri, 2017).

Several countries responded to the conditions of slowing economic growth due to the COVID-19 pandemic by issuing several policies, including Nigeria (Ejiogu, Okechukwu, \& Ejiogu, 2020). The Central Bank of Nigeria provided stimulus in the economic sector, including lowering the benchmark interest rate for loans to small-scale industries affected by the pandemic, providing loan facilities especially for industries in the health sector, devaluing the Nigerian Nira currency, and providing financial restructuring facilities for institutions. -financial institutions. The Federal Government of Nigeria is working with international donors to provide funding to accelerate economic recovery. The policy was carried out to maintain financial and social sustainability in the country. Sustainability is one of the other six dimensions of Corporate Social Responsibility (CSR) and can be found in company reports, especially those included in the financial industry. According to (Burns, Houghton, \& Stewart, 2020) sustainability or sustainability is a dimension considered in CSR in addition to economic, social, ethical, and policy. In this study, the Board of Directors did not consider the sustainability dimension because it only focused on short-term financial benefits.

One of many principle in establishing company is going concern. A company has established not for some periods but for long term period. Management as a part that has assigned by the share holder to manage the daily activity an targeted to achieve the 
company's goals, have to maintain the company's performance and their sustainability (Galuh Larasati, Isynuwardhana, \& Gani Asalam, 2019) .

The Signaling theory was first introduced by spencer in his research entitled "Job Market Signaling”. Spence (1973) argues that a signal gives a signal, the sender (the owner of the information) tries to provide pieces of relevant information that can be used by the recipient. The receiving party will then adjust its behavior according to its understanding of the signal. Meanwhile, according to Brighman and Hosuton (2014), signaling theory is a company's management behavior in guiding investors regarding management's views on the company's prospects for the future.

This theory encourages companies to provide information because of the asymmetry of information between company managers and outsiders, this is because company managers know more information about the company and its prospects. This is related to the company's financial sustainability. One of the ways companies reduce information asymmetry is by providing signals to outsiders, in the form of positive and reliable financial information that can increase the company's credibility and performance. Positive information provided by the company is related to financial reports and not related to financial reports, one of which is corporate governance information. Thus, based on Signaling theory this study examines six independent variables from two dimensions corporate governance and sensitivity of macroeconomic, a dependent variable (Financial Sustainability), and a mediating variable (financial performance), as shown in Picture 1.

Research shows that measures such as capital adequacy, asset quality, profits and profitability, liquidity, and market risk sensitivity can explain the financial sustainability of commercial banks in Ukraine (Holub, Rudevska, \& Vovchak, 2018). The increase in authorized capital in equity shows an increase in bank dependence on shareholders. Measurement of financial sustainability, especially in the banking industry, can be done using CAMEL, this method is proven to be used as a tool to measure bank solvency and predict the financial crisis that will occur. (Gutiérrez-López \& Abad-González, 2020).

Corporate governance is the principle regarding how management acts properly in running its business. The existence of independent commissioners on the board will influence management decisions and encourage the organization to disclose more of its business activities (Hashim et al., 2015). The relationship between corporate governance and the Financial Sustainability Ratio can be shown from the research of Qingrong et al. (2013), the practice of sustainable finance in the international scope shows that policies related to sustainability are determined by the board of directors (Qingrong et al., 2013). Futhermore, Satyakti (2018) stated that the financial sustainability of Islamic banks across major Muslim countries is influenced by CAR and efficiency. The CAR is a crucial factor for achieving In Financial Sustainability in the long term (Satyakti, Budiman, \& Febrian, 2018). However, in contrast to Larasati (2019) in his research, he stated that the Independent Commissioner, Board Size, Capital Adequacy Ratio, and Debt to Equity Ratio did not have a significant effect on the Financial Sustainability Ratio in bank sub-sector companies listed on the Indonesia Stock Exchange for the period 2014-2017(Galuh Larasati et al., 2019). This encourages the author to conduct an empirical test of the relationship between corporate governance and the Financial Sustainability Ratio. Several gaps exist within the measurement of the financial sustainability ratio. There are no research has been conducted to examine the relationship between corporate governance 
mechanism, sensitivity in macroeconomics, and financial sustainability ratio, especially in the pandemic. This research use stocks in the Islamic index, since some researches have shown that those stocks experienced less volatility in turbulence.

Governance mechanisms are important so that the implementation of Good Corporate Governance is carried out properly. Governance mechanisms can be grouped into two parts, namely internal governance and external governance mechanisms. According to Syahroza (2005), the internal governance mechanism consists of governance instruments within the company, namely shareholders, the GMS, the Board of Commissioners, the Board of Directors, as well as management, including the internal auditor and accounting unit. Meanwhile, the external governance mechanism consists of private (stakeholder, reputational agent), and regulatory. Independent commissioners are included in the external part of the company who are responsible for encouraging the implementation of good corporate governance (Galuh Larasati et al., 2019). Sustainable finance practices in the international scope show that policies related to sustainability are influenced by the corporate governance mechanism in this study, namely the board of directors (Qingrong et al., 2013).

$\mathrm{H}_{1}$ : Corporate Governance Mechanism is positively related with the Financial Sustainability.

According to (Sahetapy, 2019) money supply has a significant negative impact to financial sustainability in the banking sector. This means that if the money supply increase, people tend to deposit their money rather than borrowing from the bank hence it will increase the bank's cost and decrease the bank's revenue. Luciana (2004) proves that the sensitivity to money supply has a negative and statistically significant relationship with the probability of a company's delisted condition. This means that the lower the sensitivity of the company to Money Supply, the more likely a company will experience delisted.

Sensitivity to the Consumer Price Index is a description of the ability of a company to adjust to a country's inflation which is projected by the general consumer price index. Sensitivity to the Consumer Price Index has a negative and statistically significant relationship with the probability of a company being delisted. This means that the lower the sensitivity of the company to the Consumer Price Index, the more likely a company will be delisted. The relationship between sensitivity to the Consumer Price Index and the Financial Sustainability Ratio is positive, which means that the higher the sensitivity of the company to the Consumer Price Index variable, the higher the value of the Financial Sustainability Ratio will be (Almilia et.al, 2009). Meanwhile, Luciana and Meliza's (2003) research shows that the company's sensitivity to macroeconomic variables can be used to predict the company's post-IPO performance.

Interest rate is the source in generating revenue to financial institution and it should significantly contribute to attain financial sustainability. Study from (Ayayi \& Sene, 2010) has proved that interest rate has significant positive impact to financial sustainability. In this research we use BI rate as bank interest benchmark.

$\mathrm{H}_{2}$ : Sensitivity of macroeconomic is positively related with the Financial Sustainability 
Profitablity is a measurement of company's performance. An increase in profitability may indicate the good performance but may show the reverse. According to (Jeong, Shin, Kim, \& Kim, 2020) , (De Lucia, Pazienza, \& Bartlett, 2020) and (Nasfi, Syukri Iska, Nofrivul, 2019) , (Marwa \& Aziakpono, 2015) profitability is proxy in measuring financial sustainability. Study of (Sunarko, 2015) showed that profitability has significance positive impact with financial sustainability in indonesian banking industry. The increasing of profitability will increase banking sustainability. Moreover, (Jan, Marimuthu, Bin Mohd Mat Isa, \& Shad, 2019) and (Platonova, Asutay, Dixon, \& Mohammad, 2018) from their empirical studies found a positive association between sustainable business practices and the firm's financial performance in the Islamic banking industry. Their study shows that profitability and productivity has contributed towards the strong economic sustainability ratings.

Another proxy for study financial sustainability in financial institution is leverage. A research by (Semaw Henock, 2019) and (Tehulu, 2013) concluded that leverage has significant negative effect to financial sustainability in Micro Finance Institution. The research was held in Ethiopia and found that while DER is high then the institution cannot operate sustainably. Different result has found in (Sk, 2019), there was no significant effect among variables.

$\mathrm{H}_{3}$ : Financial performance is positively related with the Financial Sustainability

The Islamic capital market in Indonesia continues to grow. Financial Services Authority (OJK) noted that the number of Islamic stock investors who make transactions through the shariah online trading system (SOTS) currently has reached more than 80,000 investors. In fact, in 2016, there were only 12,000 investors. As a country with the largest Muslim population, it is hoped that the Islamic capital market can develop and become large. The Islamic index is listed on the IDX along with other indexes, namely the Indonesia Sharia Stock Index (ISSI), the Jakarta Islamic Index 70 (JII70), and the Jakarta Islamic Index (JII). In year to date (ytd), these three indices show lower performance than the Composite Stock Price Index (IHSG). Throughout 2020, ISSI recorded a decline of $14.60 \%$, JII70 corrected $14.13 \%$, and JII minus $15.83 \%$. Meanwhile IHSG only fell $12.77 \%$ (kontan.co.id). So it is necessary to do research on issuers in JII before and after the pandemic.

The problem question in this research is "Does the corporate governance, the sensitivity of macroeconomics, and the financial performance consistency related to Financial Sustainability in Islamic companies before and during the Covid-19 pandemic?" The purpose of this study is to empirically test the consistency of relationship between the Corporate Governance, the Sensitivity of macroeconomics and the financial performance to Financial Sustainability ratio in islamic companies before and during the Covid-19 pandemic. This study can contribute to providing an exposure to the consistency of the dimensions of corporate governance, macroeconomic sensitivity, and the company's financial performance to the company's financial stability during a pandemic in Indonesia. 


\section{RESEARCH METHOD}

This study is quantitative research. The data used in this study are secondary that form of financial reports obtained from the website www.idx.co.id. The financial reports studied are reports for the first quarter, second quarter, third quarter, and fourth quarter 2019 for data before the pandemic as well as the first quarter and second quarter 2020 reports for data during the pandemic. The companies studied in this study were companies listed in the Jakarta Islamic Index (JII) index in 2019 and 2020. The sampling technique used purposive sampling, with the criteria for the companies being consecutively listed in the JII index and providing the data needed in research. The samples obtained were 14 companies.

Table 1. Research Variables

\begin{tabular}{|c|c|c|}
\hline Variables & Definition & Reference \\
\hline \multicolumn{3}{|l|}{ The dependent variable } \\
\hline $\begin{array}{ll}\text { Financial } & \text { Sustainability } \\
\text { Ratio (Y) } & \end{array}$ & $\begin{array}{l}\text { This ratio is calculated by comparing total } \\
\text { financial income to total financial costs, } \\
\text { total operating costs, and retained earnings. } \\
\text { This ratio is used as an indicator of the } \\
\text { company's sustainability. }\end{array}$ & Larasati (2019) \\
\hline \multicolumn{3}{|l|}{ The independent variables } \\
\hline $\begin{array}{l}\text { The number of boards of } \\
\text { directors }\left(\mathrm{X}_{1}\right)\end{array}$ & $\begin{array}{l}\text { The number of boards of directors who } \\
\text { lead a company. }\end{array}$ & Larasati (2019) \\
\hline $\begin{array}{l}\text { The number of } \\
\text { commissioners }\left(\mathrm{X}_{2}\right)\end{array}$ & $\begin{array}{l}\text { The number of commissioners in the } \\
\text { company }\end{array}$ & Larasati (2019) \\
\hline $\begin{array}{l}\text { Proportion of independent } \\
\text { commissioners }\left(\mathrm{X}_{3}\right)\end{array}$ & $\begin{array}{l}\text { This variable is calculated by comparing } \\
\text { the number of independent commissioners } \\
\text { with the total number of commissioners. }\end{array}$ & \\
\hline $\begin{array}{l}\text { Sensitivity of } \quad \text { Money } \\
\text { Supply }\left(\mathrm{X}_{4}\right)\end{array}$ & $\begin{array}{l}\text { The money supply is data that calculates } \\
\text { the amount of money in circulation in an } \\
\text { economy. This study then used the money } \\
\text { supply variable as seen from the amount of } \\
\text { money in circulation at the end of each } \\
\text { period, as measured by the cumulative } \\
\text { regression of the company's quarterly } \\
\text { earnings. }\end{array}$ & Almilia (2009) \\
\hline $\begin{array}{l}\text { Sensitivity of the Consumer } \\
\text { Price Index }\left(\mathrm{X}_{5}\right)\end{array}$ & $\begin{array}{l}\text { The price index number is a comparison } \\
\text { between the price of a commodity or group } \\
\text { of commodities that occurs in a certain and } \\
\text { a predetermined period. Because of the } \\
\text { price data used in consumer prices, the } \\
\text { price index used is the consumer price } \\
\text { index. }\end{array}$ & Almilia (2009) \\
\hline $\begin{array}{l}\text { Sensitivity of SBI Interest } \\
\text { Rates }\left(\mathrm{X}_{6}\right)\end{array}$ & $\begin{array}{l}\text { SBIs are securities in the Rupiah currency } \\
\text { issued by Bank Indonesia as recognition of } \\
\text { short-term debt. The SBI data used is the } \\
\text { SBI at the end of each month which will }\end{array}$ & Almilia (2009) \\
\hline
\end{tabular}




\section{Variables}

The size or size of the company $\left(\mathrm{X}_{7}\right)$

Return on Asset $\left(\mathrm{X}_{8}\right)$ then be quartered.

Definition

The size or size of the company being pursued using the natural logarithm of the total assets owned by the company. ROA (Return on Asset) is an illustration to Vintila (2016) measure the bank's ability to generate profits or a measure of the company's overall ability to generate profits. ROA ratio can also be called the ratio to measure the ability of management to manage assets to generate profits (Jumingan, 2011: 245).

Debt to Equity Ratio ( $\left.\mathrm{X}_{9}\right) \quad$ DER (Debt to Equity Ratio) is the ratio of total debt to equity, which is the ratio between total debt and equity (equity). This ratio explains the large proportion of sources in long-term funding to the company's assets

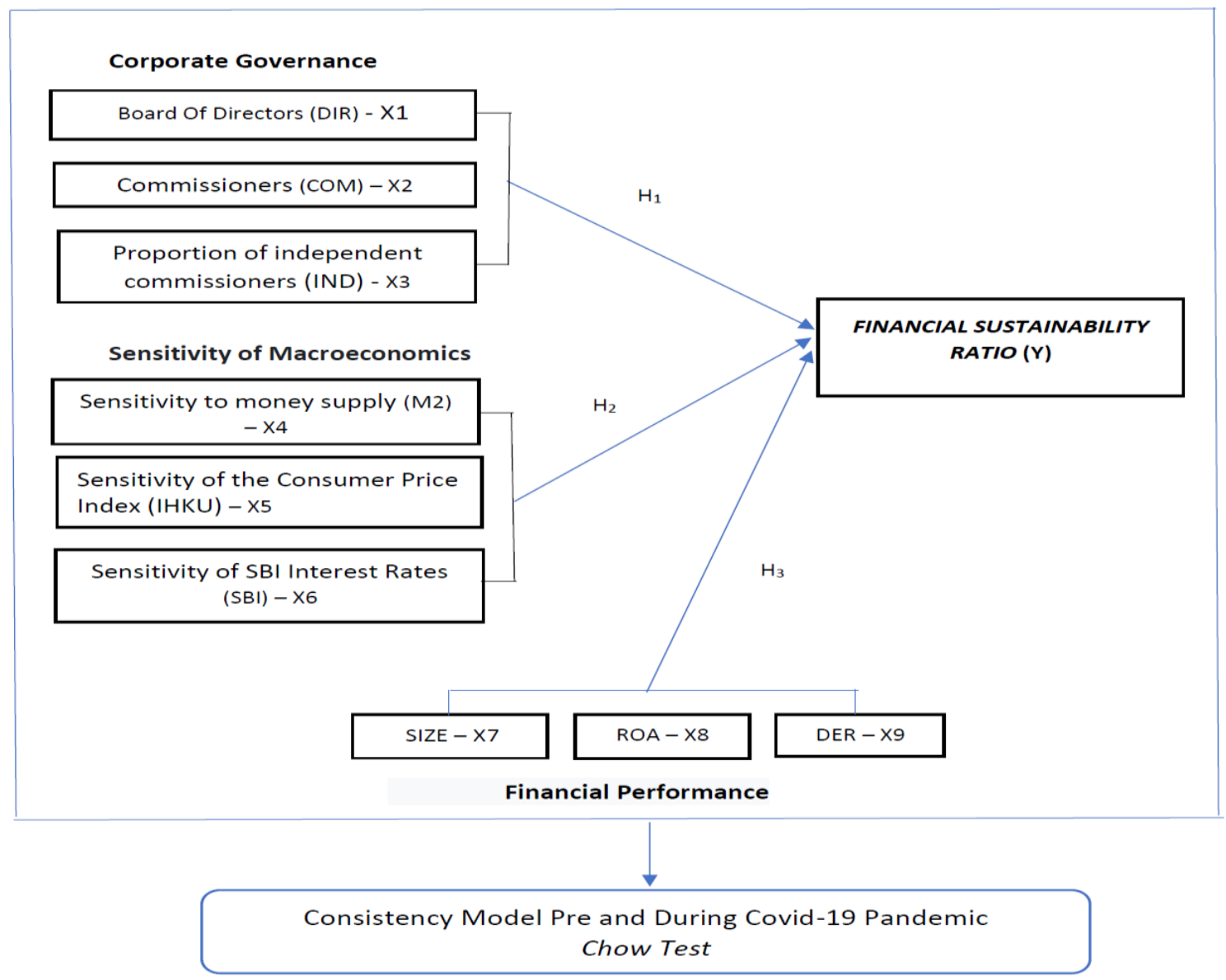

Picture 1. Theoretical Framework and Hypotheses 
To test the consistency of relationship between corporate governance, sensitivity model of macroeconomic and the financial performance in the pre-pandemic period and during the pandemic, the Chow Test structural stability test was used. Before the multiple linear regression analysis, the classical assumptions of normality, multicollinearity, autocorrelation, and heteroscedasticity were tested for each period of the pra pandemic and during the pandemic. According to Ghozali (2016:175), the Chow Test is a tool to test the test for equality of coefficients or the coefficient similarity test. The regression equation is as follows:

Pre-the Covid-19 pandemic (January - December 2019) and During the Covid-19 pandemic (January - June 2020)

$Y_{\text {it }}=\beta_{1}+\beta_{2} X_{1 i t}+\beta_{3} X_{2 i t}+\beta_{4} X_{3 i t}+\beta_{5} X_{4 i t}+\beta_{6} X_{5 i t}+\beta_{7} X_{6 i t}+\beta_{8} X_{7 i t}+\beta_{9} X_{8 i t}+\beta_{10} X_{9 i t}+e_{i t}$

Note:

$\mathrm{Y}_{\text {it }}=$ Financial Sustainability Ratio (FSR)

$\mathrm{X}_{1 \mathrm{it}}=$ Number of boards of directors (DIR)

$\mathrm{X}_{2 \mathrm{it}}=$ Number of commissioners $(\mathrm{COM})$

$\mathrm{X}_{3 \mathrm{it}}=$ Proportion of independent commissioners (IND)

$\mathrm{X}_{4 \mathrm{it}}=$ Sensitivity to money supply (M2)

$\mathrm{X}_{5 i t}=$ Sensitivity to the Consumer Price Index (IHK)

$\mathrm{X}_{6 \mathrm{it}}=$ Sensitivity to the SBI interest rate (SBI)

$\mathrm{X}_{7 \mathrm{it}}=$ Size

$\mathrm{X}_{8 \mathrm{it}}=\mathrm{ROA}$

$\mathrm{X}_{9 \mathrm{it}}=\mathrm{DER}$

$\beta_{1} \ldots \ldots \beta_{9}=$ Regression coefficient

$\mathrm{e}_{\mathrm{it}}=$ Error

The steps for carrying out the Chow Test are as follows:

1. Perform regression with total observation period (2019-2020) and get the value of the restricted residual sum of squares or $\operatorname{RSSr}(\operatorname{RSS} 3)$ with $\mathrm{df}=(\mathrm{n} 1+\mathrm{n} 2-\mathrm{k})$ where $\mathrm{k}$ is the number of parameters estimated in this case is 10 .

2. Perform regression with observations of the period before the pandemic (period January - December 2019) and get the RSS1 value with df $=(n 1-k)$.

3. Perform regression with observations of the period during the pandemic (period January - June 2020) and obtain the RSS2 value with df = (n2 - k).

4. Adding the RSS1 and RSS2 values to get what is called an unrestricted residual sum of squares (RSSur):

RSSur $=$ RSS1 + RSS2 with $d f=(n 1+n 2-2 k)$.

5. Calculating the $\mathrm{F}$ test value with the formula $\mathrm{F}=((\mathrm{RSSr}-\mathrm{RSSur}) / \mathrm{k}) /((\mathrm{RSSur}) /(\mathrm{n} 1+$ $\mathrm{n} 2-2 \mathrm{k})$ ).

6. The value of the $\mathrm{F}$ ratio follows the $\mathrm{F}$ distribution with $\mathrm{k}$ and $(\mathrm{n} 1+\mathrm{n} 2-2 \mathrm{k})$ as df for both the denominator and the numerator. 
7. If the calculated $\mathrm{F}$ value $>\mathrm{F}$ table, then we reject the null hypothesis and conclude that the regression model for the pre Covid-19 pandemic period and the during Covid-19 pandemic regression model are indeed different or in other words that the prediction model has no consistency.

\section{RESULTS AND DISCUSSION}

Financial Sustainability is the ability of an organization to compare all costs (financial costs, such as interest expense on loans, and operating costs, for example, employee salaries, equipment, supplies) with money or income received from activities performed). Financial Sustainability consists of two components, namely expenses and income. Financial sustainability is said to be good if the value is greater than $100 \%$, meaning that the total income must be greater than the total costs incurred.

Table 2. Mean of Variable at Pre Covid-19 Pandemic (2019) and During Covid-19

Pandemic (2020)

\begin{tabular}{lccccccc}
\hline \multicolumn{1}{c}{ Period } & FSR \% & M2 billion Rp & IHK & SBI & Size & ROA \% & DER \% \\
\hline Pre Pandemic & & & & & & & \\
Quarter I & 108,89 & 5.744 .200 & 135,87 & 0,06 & 17,65 & 2,30 & 86,15 \\
Quarter II & 110,90 & 5.911 .200 & 138,16 & 0,06 & 17,65 & 4,21 & 82,82 \\
Quarter III & 110,95 & 6.002 .400 & 138,37 & 0,05 & 17,67 & 6,16 & 90,14 \\
Quarter IV & 111,34 & 6.136 .500 & 139,07 & 0,05 & 17,67 & 7,98 & 87,30 \\
Rata-Rata & 110,52 & 5.948 .575 & 137,86 & 0,05 & 17,66 & 5,16 & 86,60 \\
During Pandemic & & & & & & & \\
Quarter I & 121,49 & 6.440 .500 & 104,72 & 0,05 & 17,72 & 2,29 & 94,53 \\
Quarter II & 194,02 & 6.393 .700 & 105,06 & 0,04 & 17,69 & 3,80 & 177,44 \\
Rata-Rata & 157,76 & 6.417 .100 & 104,89 & 0,04 & 17,70 & 3,04 & 135,98 \\
\hline Source· data & & & & & & &
\end{tabular}

Table 2 shows that the performance of Islamic companies in Indonesia during the pandemic in 2020 is better than before the pandemic, namely in 2019. This is indicated by the average FSR presentation in the pre-pandemic period of $110.52 \%$ and the average FSR during the pandemic experienced a significant increase. namely to be $157.76 \%$. The FSR average value of more than $100 \%$ indicates that the company can obtain revenue that is greater than the total cost they have to spend. This result is interesting for research The Covid-19 pandemic was a different time from the normal period because during the pandemic everyone was required to limit outdoor activities. The pandemic has an impact on the economic sector which causes the economy of a country to experience a sharp decline.

The money supply reflected in the amount of money has increased during the pandemic when compared to before the pandemic. This is intended to provide an economic stimulus that supports the public in making transactions to meet their daily needs during the pandemic restrictions. The price index number is the ratio between the price of a commodity or group of commodities that occurs in a certain period and a predetermined period. The Consumer Price Index during the pandemic shows a declining number, this is because during the pandemic the community reduces the purchase of secondary and tertiary goods, does not do recreation, does not use public transportation, and others. 
The level of company profitability in the first quarter of 2020 did not change when compared to the first quarter of 2019. However, a decrease in the level of profit was seen in the second quarter of 2020 by $0.41 \%$ when compared to the profit in the second quarter of 2019. The level of company size as a whole there was no change either before the pandemic or during the pandemic, this is reflected in the natural logarithm of the total assets owned by the company which did not experience any significant changes. What has changed significantly for companies during a pandemic is the level of debt reflected in the Debt to Equity Ratio. The average DER of Islamic companies increased sharply in the second quarter during the pandemic, reaching 177, 44\% which indicates that the total liabilities of the company are more than the total equity owned by the company. The Covid-19 Pandemics have a financial impact on companies by decreasing income, so companies rely on debt to cover the total costs they have to incur.

Table 3. The Result of Regression at Pre Covid-19 Pandemic (2019), During Covid-19 Pandemic (2020), and All Periode (2019-2020)

\begin{tabular}{llcccccc}
\hline No & \multirow{2}{*}{ Variable } & \multicolumn{2}{c}{ Pre Covid-19 } & \multicolumn{2}{c}{ During Covid-19 } & \multicolumn{2}{c}{ All Period } \\
& & \multicolumn{2}{c}{ Pandemic } & \multicolumn{2}{c}{ Pandemic } & \multicolumn{2}{c}{ Sig. } \\
\hline 1 & DIR & -0.109 & 0.411 & 0.014 & 0.774 & $\mathbf{0 . 0 9 2}$ & $\mathbf{0 . 0 0 4 *}$ \\
2 & COM & $\mathbf{- 0 . 0 8 8}$ & $\mathbf{0 . 0 1 3} *$ & -0.046 & 0.347 & $\mathbf{- 0 . 0 8 5}$ & $\mathbf{0 . 0 0 4}$ \\
3 & IND & $\mathbf{2 . 7 2 2}$ & $\mathbf{0 . 0 0 0} *$ & -0.046 & 0.351 & -0.059 & 0.244 \\
4 & M2 & 0.018 & 0.867 & 0.025 & 0.621 & 0.006 & 0.897 \\
5 & IHK & 0.022 & 0.842 & -0.025 & 0.621 & $\mathbf{- 0 . 2 0}$ & $\mathbf{0 . 0 0 1} *$ \\
6 & SBI & $-0,011$ & 0.922 & 0.025 & 0.621 & $\mathbf{3 4 . 3 5 5}$ & $\mathbf{0 . 0 1 3}$ \\
7 & SIZE & $\mathbf{0 . 2 2 1}$ & $\mathbf{0 . 0 0 1} *$ & -0.054 & 0.254 & -0.015 & 0.834 \\
8 & ROA & -0.049 & 0.675 & $\mathbf{1 3 . 0 5 3}$ & $\mathbf{0 . 0 0 0} *$ & $\mathbf{7 . 7 9 1}$ & $\mathbf{0 . 0 0 0} *$ \\
9 & DER & 0.025 & 0.838 & $\mathbf{0 . 0 7 3 9}$ & $\mathbf{0 . 0 0 2} *$ & $\mathbf{0 . 7 3 8}$ & $\mathbf{0 . 0 0 0} *$ \\
\hline
\end{tabular}

Source: data processed

Before doing regression testing and chow test, testing the classical assumptions of normality, multicollinearity, autocorrelation, and heterogeneity for each period. And the results of testing the classical assumptions of each period show that the model used is normally distributed and is free from multicollinearity, autocorrelation, and heteroscedasticity. The difference between the prediction models for the period before and during the pandemic was tested using the difference Chow Test. In the Chow Test, the Multiple Linear Regression Analysis must be performed first using the stepwise method.

The results of regression testing in the period Pra Covid-19 (2019), during Covid-19 (2020), and all periods (2019-2020) in Table 3 show that the nine variables have varying levels of significance. In the period Pre the Covid-19 pandemic (2019), three variables affected the Financial Sustainability Ratio, namely the variable of the board of commissioners (sig 0.013), the proportion of independent board of commissioners (sig. 0.000), and company size (0.001). Meanwhile, during Covid-19 period (2020), the variables Return on Assets (ROA) (sig. 0.000) and Debt to Equity (DER) (sig. 0.002) had a significant effect on the Financial Sustainability Ratio.

Overall, for the whole period $(2019$ - 2020) the variable period that has a significant effect on the Financial Sustainability Ratio is the variable of the board of directors (sig. 
0.004), the board of commissioners (sig. 0.004), the Consumer Price Index (sig. 0.001), interest rates (sig. 0.013), Return on Assets (ROA) (sig. 0.000) and Debt to Equity (DER) (sig. 0.000). The regression results indicate that each factor has a variable that affects the Financial Sustainability Ratio. The influential variables of corporate governance are the board of directors and the board of commissioners; Macro factors that influence are the Consumer Price Index and interest rates; while the financial performance factor is represented by the variable Return on Assets and Debt to Equity Ratio which affects the Financial Sustainability Ratio.

The results of this study are in line with the research of Qingrong et al. (2013) and Syahroza (2005) which state that the board of directors and Independent commissioner is an internal and external part of the company who is responsible for encouraging the implementation of good corporate governance. But not in line with Larasati (2019) stated that the Independent Commissioner and Board Size did not have a significant effect on the Financial Sustainability Ratio in bank sub-sector companies. Likewise with the profitability is proxy in measuring financial sustainability. This is in accordance with the research of (Jeong et al., 2020), (De Lucia et al., 2020) and (Nasfi, Syukri Iska, Nofrivul, 2019) and (Marwa \& Aziakpono, 2015).

The Chow Test is carried out to see the consistency of the financial sustainability prediction model for companies listed on the Jakarta Islamic Index for the period 2019 to the second quarter of 2020. The results of all regressions show the residual-residual value that will be used to calculate the calculated $\mathrm{F}$ value. The results of the regression residuals throughout the period are the so-called RSSr (restricted residual sum of squares) of 14,706. In the regression before the pandemic, the residual value was 4.246; in regression during the pandemic, the residual value is 5.529 which is then added to the unrestricted residual sum of squares of 9.775; The result of the RSSr is reduced by the result of the RSSur and divided by $\mathrm{k}$, where $\mathrm{k}$ is equal to the number of independent variables tested, namely 10 . Then divided by the result of dividing the RSSur by 80 of the values $(n 1+n 2-2 k)$. Thus, the calculated $\mathrm{F}$ value is 20.2 and from the $\mathrm{F}$ table with $\mathrm{df}=9$ and 80 a significant level of 0.05 is obtained $\mathrm{F}$ table of 2.10; The calculated $\mathrm{F}$ value is compared to the $\mathrm{F}$ table, then the calculated F value> F table. So it can be concluded that the pandemic period in Indonesia affected the financial stability of companies listed on the Jakarta Islamic Index. In other words, the relationship of independent variables consisting of corporate governance (board of directors, the board of commissioners, and proportion of independent commissioners), macroeconomic variables (supply-demand, consumer price index, and interest rates), and the company's financial performance (size, ROA, and DER) on the dependent variable Financial Sustainability Ratio experiencing structural changes in Indonesia in the period 2019 - 2020. So this research concludes that the prediction model of financial performance at the Jakarta Islamic Index companies no consistent in the period 2019 - 2020.

Based on the hypothesis developed, it can be explained that the corporate governance and microeconomic sensitivity cannot be predict consistency of Financial Sustainability before and during the Covid-19 pandemic. The financial performance through profitability that can predict the consistency of Financial Sustainability before and during the Covid-19 pandemic. This implies that when analyzing the consistency of the model, changes in the factors of Corporate Governance (CG) and Sensitivity of macroeconomic needs attention. 
Companies listed in Jakarta Islamic Index are able to provide good signals and are able to reduce information asymmetry to shareholders so that based on the company's financial statements the shareholders still believe in investing their funds in the company. Another implication of this research in practice is that when Jakarta Islamic Index companies build models to predict the consistency of financial sustainability, the thing that needs to be analyzed is that there is economic development from time to time which causes the model to be dynamic and not static.

\section{CONCLUSION}

The financial sustainability ratio of companies at the time of the pandemic has a higher value than before the pandemic, this shows that the company further improves financial stability to save the company during the pandemic. The macroeconomic factor during the pandemic has decreased, this is because the government has taken macro policies that alleviate society during difficult times such as this pandemic. The value of the Consumer Price Index has decreased due to the reduced level of public consumption of tourism, restaurants, hotels, and others. Bank Indonesia also set the SBI interest rate to be smaller, this is intended to help the public in lending. The amount of money in circulation during the pandemic has increased because the government has provided a stimulus for the public to re-conduct economic transactions in the retail sector.

This study tested the consistency of independent variables, namely corporate governance factors (board of directors, the board of commissioners, and proportion of independent commissioners), sensitivity of macroeconomic variables (supply-demand, consumer price index, and interest rates), and company's financial performance (size, ROA, and DER) on the dependent variable Financial Sustainability Ratio. The results obtained are that the financial stability of companies listed on the Jakarta Islamic Index is influenced by the Indonesian government policy that determines the status of Pandemic in 2020.

The pandemic is still ongoing today, it is very well aware that in writing this study there are still obstacles, especially related to the data used. This study has several limitations, namely : 1) the quarterly financial reports of JII during Covid-19 still incomplete, causing the calculation of financial ratios to be difficult to generalize and 2) This study only uses three sensitivity to macroeconomic variables Money Supply, General Consumer Price Index and and SBI Interest Rates.

With consideration of its limitations owned, then some suggestions can be made for further research. It is hoped that the next study can extend the observation period so that the findings become reliable as one of the theoretical contributions related to research during the pandemic era in the capital market and investment in Indonesia. Addition of the types of variables used to predict the consistency of Financial Sustainability.

\section{REFRENCES}

Ayayi, A. G., \& Sene, M. (2010). What Drives Microfinance Institution's Financial Sustainability Author ( s ): Ayi Gavriel Ayayi and Maty Sene Source : The Journal of Developing Areas, Vol . 44 , No . 1 ( Fall 2010 ), pp . 303-324 Published by : College of Business , Tennessee State U. The Journal of Development Areas, 44(1), 303-324.

Burns, C. J. M., Houghton, L., \& Stewart, H. (2020). Sustainability - A key to Australian finance directors improving their organisation's CSR culture. Corporate Social Responsibility and Environmental Management, 27(2), 1164-1176.

Chen Chun-Da , Chen Chin-Chun, T. W.-W., \& Bor-Yi, H. (2009). The Positive and 
Negative Impacts of the Sars Outbreak : A Case of the Taiwan Industries. The Journal of Developing Areas, 43(1), 281-293.

De Lucia, C., Pazienza, P., \& Bartlett, M. (2020). Does good ESG lead to better financial performances by firms? Machine learning and logistic regression models of public enterprises in Europe. Sustainability (Switzerland), 12(13), 1-26.

Del Giudice, A., \& Paltrinieri, A. (2017). The impact of the Arab Spring and the Ebola outbreak on African equity mutual fund investor decisions. Research in International Business and Finance, 41(May), 600-612.

Ejiogu, A., Okechukwu, O., \& Ejiogu, C. (2020). Nigerian budgetary response to the COVID-19 pandemic and its shrinking fiscal space: financial sustainability, employment, social inequality and business implications. Journal of Public Budgeting, Accounting and Financial Management.

Galuh Larasati, D., Isynuwardhana, D., \& Gani Asalam, A. (2019). Corporate Governance, Rasio-Rasio Keuangan Dan Financial Sustainability Pada Perbankan Umum Di Indonesia (Studi Pada Perusahaan Perbankan yang Terdaftar di Bursa Efek Indonesia peri-ode 2014-2017). ISEI Accounting Review, III(2), 39-43. Retrieved from http://jurnal.iseibandung.or.id/index.php/iar

Gutiérrez-López, C., \& Abad-González, J. (2020). Sustainability in the banking sector: A predictive model for the European banking union in the aftermath of the financial crisis. Sustainability (Switzerland), 12(6).

Holub, R., Rudevska, V., \& Vovchak, O. (2018). Peculiarities of ensuring financial sustainability of the Ukrainian banking system. Banks and Bank Systems, 13(1), 184195.

Jan, A., Marimuthu, M., Bin Mohd Mat Isa, M. P., \& Shad, M. K. (2019). Bankruptcy forecasting and economic sustainability profile of the market leading Islamic banking countries. International Journal of Asian Business and Information Management, 10(2), 73-90. https://doi.org/10.4018/IJABIM.2019040104

Jeong, H., Shin, K., Kim, E., \& Kim, S. (2020). Does open innovation enhance a large firm's financial sustainability? A case of the Korean food industry. Journal of Open Innovation: Technology, Market, and Complexity, 6(4), 1-17.

Karlsson, M., Nilsson, T., \& Pichler, S. (2014). The impact of the 1918 Spanish flu epidemic on economic performance in Sweden. An investigation into the consequences of an extraordinary mortality shock. Journal of Health Economics, $36(1), 1-19$.

Marwa, N., \& Aziakpono, M. (2015). Financial sustainability of Tanzanian saving and credit cooperatives. International Journal of Social Economics, 42(10), 870-887.

Nasfi, Syukri Iska, Nofrivul, A. (2019). Financial Sustainability Inthe Assessment of Thefinancial Performance of West Sumatra Sharia Financing Bank (BPRS). Menara Ekonomi, 5(1), 51-62.

Nuraini, N., S, K. K., \& Apri, M. (2020). Data dan Simulasi COVID-19 dipandang dari Pendekatan Model Matematika Akumulasi kasus COVID-19: Italia.

Platonova, E., Asutay, M., Dixon, R., \& Mohammad, S. (2018). The Impact of Corporate Social Responsibility Disclosure on Financial Performance: Evidence from the GCC Islamic Banking Sector. Journal of Business Ethics, 151(2), 451-471. https://doi.org/10.1007/s10551-016-3229-0 
Sahetapy, K. A. (2019). The Relationship Between Macroeconomy Factors and Indonesian Banks' Financial Sustainability. Abstract Proceedings International Scholars Conference, 7(1), 1204-1216.

Satyakti, Y., Budiman, T., \& Febrian, E. (2018). Islamic Bank Financial Sustainability: A Micro Econometric Approach. SSRN Electronic Journal, (January). https://doi.org/10.2139/ssrn.3259055

Semaw Henock, M. (2019). Financial sustainability and outreach performance of saving and credit cooperatives: The case of Eastern Ethiopia. Asia Pacific Management Review, 24(1), 1-9. Retrieved from https://doi.org/10.1016/j.apmrv.2018.08.001

Sk, B. (2019). The Moderating Effect of Depth of Outreach on the Relationship between Financial Leverage and Financial Sustainability of Microfinance Institution. Journal of Economic Business Studies, 2(7).

Spence, M. (1973). Job Market Efficiency. The Quarterly Journal of Economics. 87(3), 355-374.

Sunarko, A. E. S. dan M. R. (2015). Pengaruh Variabel Rasio Keuangan Terhadap Financial Sustainability Ratio Pada Bank Campuran Periode 20011-2013. Eksplorasi, 27(2), 10 .

Tehulu, T. A. (2013). Determinants of Financial Sustainability of Microfinance Institutions in East Africa. European Journal of Business and Management, 5(17), 152-159.

Vintila, G and Paunescu, R. A. (2016). Empirical Analysis of the Connection between Financial Performance and Corporate Governance within Technology Companies Listed on NASDAQ Stock Exchange. Journal of Financial Studies \& Research.

Wang, Y. H., Yang, F. J., \& Chen, L. J. (2013). An investor's perspective on infectious diseases and their influence on market behavior. Journal of Business Economics and Management, 14(SUPPL1), 112-127. 